\title{
A case report of extralobar pulmonary sequestration in a dog
}

\author{
Reza Kheirandish ${ }^{1 *}$, Shahrzad Azizi ${ }^{2}$, Soodeh Alidadi ${ }^{3}$ \\ ${ }^{1}$ Department of Pathobiology, School of Veterinary Medicine, Shahid-Bahonar University of Kerman, Kerman, Iran \\ ${ }^{2}$ Department of Pathology, School of Veterinary Medicine, Islamic Azad University, Shahrekord Branch, Shahrekord, Iran \\ ${ }^{3}$ School of Veterinary Medicine, Shahid-Bahonar University of Kerman, Kerman, Iran
}

\section{ARTICLE INFO}

Article history:

Received 20 October 2011

Received in revised form 20 November 2011

Accepted 4 December 2011

Available online 28 April 2012

Keywords:

Extralobar pulmonary sequestration

Dog

Histopathology

\begin{abstract}
Pulmonary sequestration is a rare congenital anomaly in the veterinary literature. This malformation is characterized by a cystic mass of non-functioning primitive lung tissue that does not communicate with the tracheobronchial tree or with the pulmonary arteries. This article describes gross and histopathological characteristics of extralobar pulmonary sequestration in a dog. Grossly, a mass was observed in the left side of the thoracic cavity, closed to the caudal lobes of the lung, without communication with the tracheobronchial tree and the pulmonary arteries that was separated by pleural covering. Histopathologic examination showed emphysematous alveoli and bronchi, hypertrophy of smooth muscles and presence of the undifferentiated mesenchymal tissue. Therefore, based on microscopic findings, extralobar pulmonary sequestration was diagnosed. To the best of our knowledge, this is the first report of extralobar pulmonary sequestration in dog.
\end{abstract}

\section{Introduction}

Congenital anomalies of the lungs are rare in all species but most commonly reported in cattle and sheep[1]. Pulmonary sequestration is a rare congenital malformation which is characterized by a cystic mass of non-functioning primitive lung tissue that does not communicate with the tracheobronchial tree or with the pulmonary arteries. It is supplied by an anomalous artery arising from aorta and venous drainage is via the azygos system, pulmonary veins or the inferior vena cava[2]. Two types of pulmonary sequestration are recognized, depending on whether or not the malformation possesses its own pleural covering. Extralobar sequestration is in conformity with a true accessory lung, with its own pleural envelope and accounts for $15 \%-25 \%$ of all pulmonary sequestrations. Intralobar sequestration is an abnormal region within the normal

\footnotetext{
*Corresponding author: Reza Kheirandish, Department of Pathobiology, School of Veterinary Medicine, Shahid-Bahonar University of Kerman, Kerman, Iran.

Tel: +983413202950

Fax: +983413222047

E-mail:kheirandish@uk.ac.ir
}

pulmonary parenchyma without its own pleural covering and represents approximately $75 \%-85 \%$ of all pulmonary sequestrations that suggesting it be more common[2,3]. In human medical literature, the same term 'accessory lung or accessory lobe' was renamed as pulmonary sequestration to define abnormal mass of non-functioning development of lung tissue anywhere in the body[4]. To the best of our knowledge, extralobar pulmonary sequestration has not been previously reported in dog. The present report describes gross and histopathological characteristics of extralobar pulmonary sequestration in a dog.

\section{Case report}

An apparently healthy 6-month-old male mixed breed dog was euthanized by standard methods of Iranian Veterinary Organization rules and necropsied in necropsy room of the Pathology Department, Veterinary Faculty, Shahid-Bahonar University of Kerman, Kerman, Iran, for teaching. At necropsy, a pinkish ovoid-shaped mass, with $(3 \mathrm{~cm} \times 5 \mathrm{~cm})$ in dimension and spongy texture was observed in the left side of the thoracic cavity, closed to the caudal 
lobes of the lung and possessed its own pleural covering (Figure 1). The pulmonary mass had no communication with the tracheobronchial tree and with the pulmonary arteries. No other abnormality in the affected lung and other organs was present.

Samples of the mass were taken and fixed in 10\% neutral buffered formalin and processed according to the routine of histopathologic technique. Paraffin sections at $5 \mu \mathrm{m}$ thickness were stained with hematoxylin and eosin and studied with ordinary light microscope.

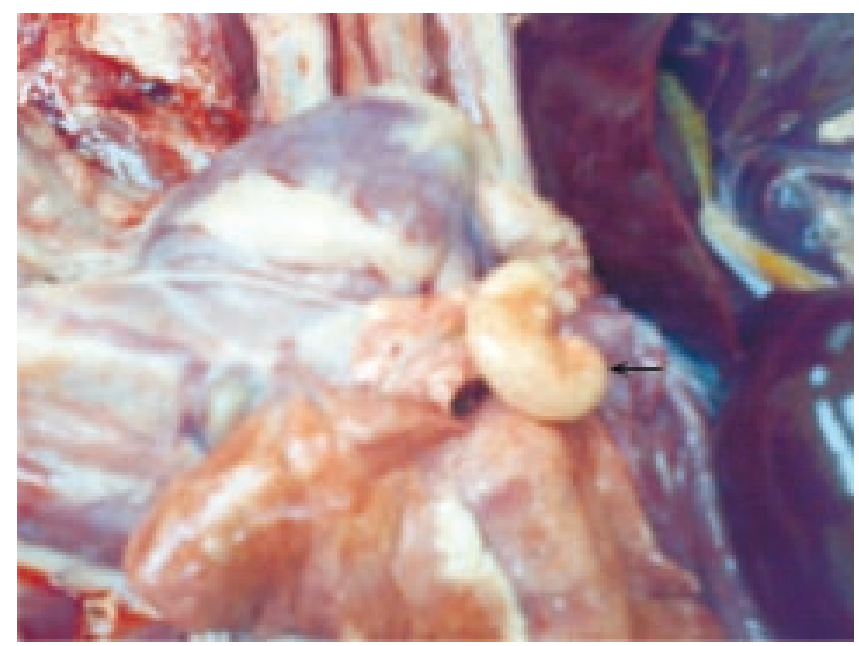

Figure 1. Pulmonary sequestration as a separated, ovoid-shape and pink mass in the thoracic cavity (arrow).

Microscopic examination of the tissue specimens revealed that the mass had histologic characteristics similar to a lung tissue but alveoli and bronchi were emphysematous (Figure 2). In some areas, congestion, alveolar collapse, hypertrophy of smooth muscles and presence of the undifferentiated mesenchymal tissue were observed.

On the basis of gross and histological findings, the diagnosis of extralobar pulmonary sequestration was made.

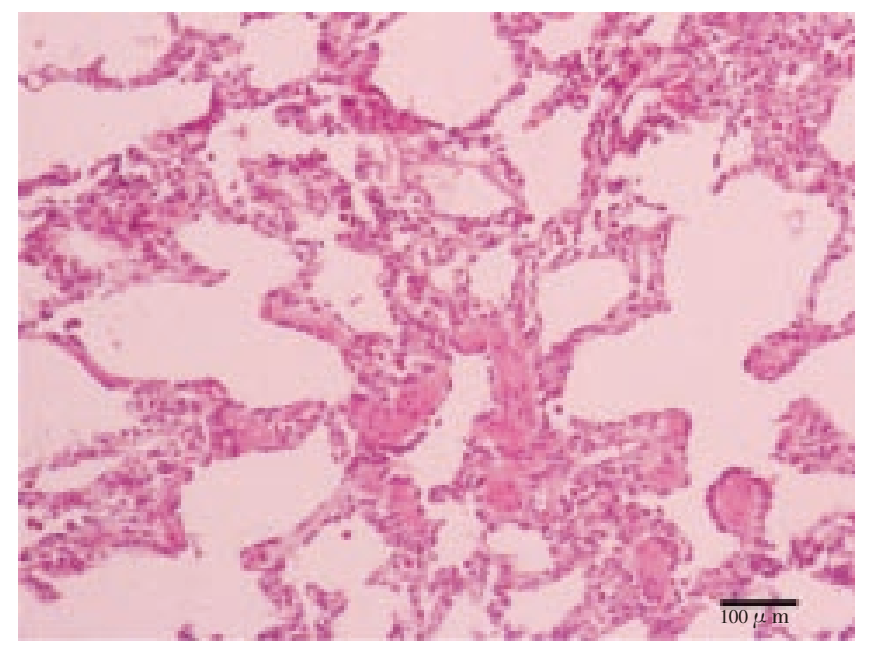

Figure 2. The lung tissue with emphysematous and dilated alveoli, and hypertrophy of smooth muscles (H\&E stain).

\section{Discussion}

Pulmonary sequestration is an uncommon type of congenital pulmonary malformation characterized by relatively abnormal pulmonary parenchyma that has no connection with tracheobronchial tree and vascularised by systemic artery. Although there are several reports on extralobar pulmonary sequestration in human, but only a few reports of occurrence of this anomaly are present in the veterinary literature[4-6]. In humans, pulmonary sequestration represents between $0.15 \%$ and $6.45 \%$ of all pulmonary malformations[7,8]. Two different forms of pulmonary sequestration have been recognized as intralobar and extralobar, that recent form seems to be more uncommon. Both extralobar and intralobar sequestration can show patent communication with the foregut that more frequently reported for the extralobar form (also called congenital bronchopulmonary foregut malformation)[9]. Both types have arterial supply from the thoracic or abdominal aorta. Extralobar sequestration is enclosed completely in its own pleural sac. There are numerous differences between these two types including: 1) intralobar form is always drained by the pulmonary veins whilst extralobar disease is drained by the azygous or portal vein[2,10,11]; 2) intralobar form is approximately equally distributed between sexes whilst extralobar disease is found more commonly in males $(80 \%$ of cases, a male-to-female ratio of 4:1)[2,3,12]; 3) intralobar sequestrations are not associated with other cardio-pulmonary anomalies, but extralobar sequestrations may be found in association with congenital anomalies, including congenital diaphragmatic hernia, cardiac malformations, congenital cystic adenomatoid malformation and gastrointestinal malformations[2,8,12-14]; 4) intralobar sequestration demonstrates no preferences for either lung whilst extralobar sequestration is found in the left lung in $80 \%-90 \%$ of cases[11,12,15]; 5) the etiology of intralobar sequestration remains controversial, but extralobar sequestrations are commonly considered to be of congenital origin and are included in bronchopulmonary foregut malformations $[8,10,15]$; 6) the extralobar form is most commonly diagnosed in the prenatal and neonatal periods, whereas the intralobar form is usually diagnosed in childhood[3,10,16].

Pulmonary sequestration may be present in the normal lung of the thoracic cavity, any side of diaphragm or in a subdiaphragmatic position[2,10]. Most frequently supported theory of how a sequestration arises is that an accessory lung bud develops from the ventral aspect of the primitive gut[2,17]. The pleuropotential tissue from this additional lung bud migrates in a caudal direction with the normally developing lung. It receives its blood supply from vessels that connect to the aorta and that cover the primitive gut. The attachments to the aorta remain to form the systemic arterial supply of the sequestration. If accessory lung 
bud develops in early embryonic period, it results in formation of sequestration within normal lung tissue and encasement within the same pleural covering. In contrast, later development of the accessory lung bud results in the extralobar type[2,17,18]. A spiral CT with contrast angiography and magnetic resonance imaging (MRI) are the diagnostic techniques of choice[5,7,11,19-26]. The treatment of an extralobar sequestrum is mainly by surgical excision which removes the mass completely total of the sequestrum to reduce the risk of repeated infection[2,5,7,19,20,27-29]. To the best of our knowledge, this study is the first reported case of extralobar pulmonary sequestration in a mixed-breed dog that describes.

\section{Conflict of interest statement}

We declare that we have no conflict of interest.

\section{Acknowledgments}

We are thankful to Mr. Hassanzadeh for his excellent technical assistance.

\section{References}

[1] McGavin MD, Zachary JF. Pathologic basis of veterinary disease. 4th ed. St. Louis: Mosby Elsevier; 2011, p. 493 .

[2] Shah MS, Bhatt CB, Modi JM. Case report: extra lobar pulmonary sequestration. Indian J Radiol Imaging 2003; 13: 271-273.

[3] Ulys A, Samalavicius NE, Cicenas S, Petraitis T, Trakymas M, Gatijatullin L. Extralobar pulmonary sequestration. Int Med Case Rep J 2011; 4: 21-23.

[4] Canpolat I, Eroksuz Z. Pulmonary sequestration and bronchogenic cyst in a calf. Firat Univ Saglik Bilimleri Dergisi 2007; 21(6): 281-284.

[5] Wei Y, Li F. Pulmonary sequestration: a retrospective analysis of 2625 cases in China. Eur J Cardiothorac Surg 2011; 40: e39-e42.

[6] Lewis BS, Hubbard GB, Mense MG, Frost PA. Congenital bronchioloalveolar airway malformation in a cynomolgus macaque (Macaca fascicularis). J Med Primatol 2005; 34: 41-44.

[7] Melfi FMA, Viti A, Davini F, Mussi A. Robot-assisted resection of pulmonary sequestrations. Eur J Cardiothorac Surg 2011; 40: 1025-1026.

[8] Furukawa S, Takaya A, Nakagawa T, Sakaguchi I, Nishi K. Extralobar pulmonary sequestration: an autopsy case. Rom J Leg Med 2010; 18: 179-182.

[9] Takeuchi Y, Yoshida T, Chiba Y, Kuwahara M, Maita K, Harada T. Pulmonary sequestration with ectopic pancreatic tissue in a Wistar Hannover GALAS rat. Toxicol Pathol 2002; 30: 288-291.

[10] Ho VB, Momeni A, Hood MN, Carter WR. Intralobar bronchopulmonary sequestration. Milit Med 2006; 172(1): 8-9.

[11] Gonzalez D, Garcia J, Fieira E, Paradela M. Video-assisted thoracoscopic lobectomy in the treatment of intralobar pulmonary sequestration. Interact Cardio Vasc Thorac Surg 2011; 12: 77-79.

[12] Kaselas C, Papouis G, Grigoriadis G, Kaselas V. Secondary diaphragmatic eventration after resection of extralobar pulmonary sequestration. J Indian Assoc Pediatr Surg 2007; 12: 92-93.

[13] Huang EY, Monforte HL, Shaul DB. Extralobar pulmonary sequestration presenting with torsion. Pediatr Surg Int 2004; 20: 218-220.

[14] Lima M, Randi B, Gargano T. Extralobar pulmonary sequestration presenting with torsion and associated hydrothorax. Eur J Pediatr Surg 2010; 20: 208-210.

[15] Arslanian A, Leflour N, Hernigou A, Danel C, Riquet M. Complex extralobar sequestration in a 24 year old woman. Ann Thorac Surg 2003; 76: 2077-2078.

[16] Prasad R, Garg R, Verma K. Intralobar sequestration of lung. Lung India 2009; 26(4): 159-161.

[17] Bruce M, Schnapf DO. Pediatric pulmonary sequestration. E-Med $J 2003$.

[18] Osaki T, Kodate M, Takagishi T, Nomi M, Murakami J, Yamamoto H. Unique extralobar sequestration with atypical location and aberrant vessels. Ann Thorac Surg 2010; 90(5): 1711-1712.

[19] Yucel O, Gurkok S, Gozubuyuk A, Caylak H, Sapmaz E, Kavakli K, et al. Diagnosis and surgical treatment of pulmonary sequestration. Thorac Cardiovasc Surg 2008; 56(3): 154-157.

[20] Kestenholz PB, Schneiter D, Hillinger S. Thoracoscopic treatment of pulmonary sequestration. Eur J Cardiothorac Surg 2006; 29: 815-818.

[21] Fumino S, Iwai N, Kimura O, Ono S, Higuchi K. Preoperative evaluation of the aberrant artery in intralobar pulmonary sequestration using multidetector computed tomography angiography. J Pediatr Surg 2007; 42(10): 1776-1779.

[22] Sancak T, Cangir AK, Atasoy C, Ozdemir N. The role of contrast enhanced three-dimensional MR angiography in pulmonary sequestration. Interact Cardiovasc Thorac Surg 2003; 2(4): 480-482.

[23] Lee BS, Kim JT, Kim EA, Kim KS, Pi SY, Sung KB, et al. Neonatal pulmonary sequestration: clinical experience with transumbilical arterial embolization. Pediatr Pulmonol 2008; 43(4): 404-413.

[24] Smart LM, Hendry GM. Imaging of neonatal pulmonary sequestration including Doppler ultrasound. Br J Radiol 1991; 64(760): 324-329.

[25] Ooi GC, Cheung CW, Lam WK, Tsang KW. Pulmonary sequestration: diagnosis by magnetic resonance angiography and computed tomography. Chin Med J 1999; 112(7): 668-670.

[26] Amitai M, Konen E, Rozenman J, Gerniak A. Preoperative evaluation of pulmonary sequestration by helical CT angiography. Am J Roentgenol 1996; 167(4): 1069-1070.

[27] Al-Muffarej F, Margolis M, Tempesta B, Strother E, Gharagozloo F. Robot assisted thoracoscopic resection of intralobar sequestration. J Laparoendosc Adv Surg Tech A 2009; 19(3): 389-391.

[28] Genç O, Gürkök S, Dakak M, Gözübüyük A, Ozkan M, Caylak H. Pulmonary sequestration and surgical treatment. Asian Cardiovasc Thorac Ann 2006; 14: 3-6.

[29] Nicolini U, Cerri V, Groli C, Poblete A, Mauro F. A new approach to prenatal treatment of extralobar pulmonary sequestration. Prenat Diagn 2000; 20: 758-760. 